\title{
Studies on mosquitoes (Diptera: Culicidae) and anthropic environment. 10- Survey of adult behaviour of Culex nigripalpus and other species of Culex (Culex) in South-Eastern Brazil*
}

\author{
Oswaldo Paulo Forattini, Iná Kakitani, Eduardo Massad, Daniel Marucci
}

Departamento de Epidemiologia, Faculdade de Saúde Pública, Universidade de São Paulo. Núcleo de Pesquisa Taxonómica e Sistemática em Entomologia Médica (NUPTEM) Såo Paulo Brasil (O.P.F., I.K., D.M.),

Departamento de Patologia, Faculdade de Medicina, Universidade de São Paulo - São Paulo Brasil (E.M.)

\begin{abstract}
A survey of adult behaviour of Culex (Culex) species was carried out from August 1992 through December 1993 in a human modified (anthroplc) environment in the Ribelra Valley, S.Paulo State, Brazil. Culex nigripalpus dominated the catches at several sites and it's tendency to increase in the anthropic environment became quite clear. Nevertheless no high level of synanthropy was demonstrated. So it seems that the mosquito may have a restricted role in natural arbovirus cycles. Nonetheless, $C x$. nigripalpus must be considered a potential vector of arboviruses, especlally St. Louis encephalitis virus outside dwellings.
\end{abstract}

Culex. Ecology, vectors. St. Louis encephalitis, transmission.

\section{Introduction}

From the epidemiological point of view Culex (Culex) is a group of mosquitoes that includes several arbovirus vector species. They are essentially nocturnal-crepuscular tending to be active throughout the night, but most are active just after dark. In general, these mosquitoes are mainly ornithophilic and thus they cycle virus agents among avian hosts. Nevertheless, important differences exist according to weather and peculiar environmental conditions that may influence their role as an arbovirus vector. In North America, species of the Culex subgenus are important in the transmission of mosquito-borne arboviruses of public health importance such as eastern (EEE), western (WEE) and St. Louis (SLE) encephalitis. Culex nigripalpus is considered to be an important SLE vector in the southeastem United States, and perhaps EEE virus as well (Chamberlain et al. ${ }^{2}, 1964$; Dow et al. ${ }^{4}, 1964$; Morris $^{27}, 1992$ ).

In Central and South America, Cx. nigripalpus was considered as a potential vector of EEE virus in the Dominican Republic (Mitchell et al. ${ }^{25}$, 1979). In addition, an isolation of vesicular stomatitis New Jersey (VSNJ) virus was obtained from this species in Guatemala (C.H.Calisher apud Webb and Holbrook $^{29}, 1988$ ), and isolations of others virus were reported from this mosquito in Panama (Dutary et al. $\left.{ }^{5}, 1984\right)$. Isolations of SLV from $C x$. nigripalpus were obtained in Jamaica and Guatemala (Belle et al. ${ }^{1}, 1964$; Cupp et al. ${ }^{3}, 1986$ ). In Argentina, natural infections by SLE virus were reported in $C x$. quinquefasciatus and undetermined $C x$. (Culex) specimens (Mitchell et al, ${ }^{26}, 1985$ ). In the brazilian Amazon region, SLE virus was isolated from $C x$. coronator, $C x$. declarator and unidentified $C x$. (Culex) mosquitoes which also provided Mucambo virus isolations (Vasconcelos et al. ${ }^{28}, 1991$ ). The relative importance of all these neotropical culicids in the maintenance and transmission of these arboviruses, particularly SLE virus in Latin America, remains to be defined.

Observations on mosquito behaviour were made during a research program in the Ribeira Valley region of S. Paulo State, subsequent to an

\footnotetext{
* Research supported by "Fundaçdo de Amparo d Pesquisa do Estado de Säo Paulo (FAPESP)" (Grant no. 90/3371-6). Reprints: Oswaldo Paulo Forartini - Departamento de Epidemiologia, Faculdade de Saúde Pública, Universidade de Sđo Paulo. Núcleo de Pesquisa Taxonômica e Sistemática em Entomologia Médica (NUPTEM). Av. Dr. Arnaldo, 715 - 0I246-904 - São Paulo, SP - Brasil - Fax: (01I) 282.1898 E.Mail op forati @ usp. br

The publication of this article was supported by FAPESP (Process 95/2290-6).

Received in 3.28.1995. Approved in 6.16.1995.
} 
encephalitis epidemic started in 1975-1976 thereafter decreasing until 1983 (Iversson $^{21}, 1988$ ). Culicidae were studied regarding their dominance, biting habits, synanthropy and geographic distribution (Forattini et al. ${ }^{6.7,8.10,11}, 1981,1986,1989$, 1990). More recently, observations were performed at a rural man-made environmental sites where artificial irrigation is used for rice cultivation, focusing on several species including some Culex (Culex) found there (Forattini et al. ${ }^{12,13,14,15} 1993$, 1994). A continuation of these researches in that anthropic environment focused on mosquito biting activities and occurrence at several places. During 1992-1993, adults were collected through the use of human bait and Shannon-type traps. The results regarding the subgenus Culex species are presented here for the purpose of revealing epidemiological evidence about their potential hypothetical vector role.

\section{Study areas and methods}

Adult sampling followed the same study areas and methods have been described elsewhere (Forattini et al. ${ }^{16.17}, 1995$ ). To make it easier to understand the results presented, the sampling sites are noted again.

Shannon traps (Shan) collections:

\begin{tabular}{|c|c|c|c|}
\hline Period & Site & Place & $\begin{array}{l}\text { Shannor } \\
\text { trap }\end{array}$ \\
\hline \multirow{3}{*}{$\begin{array}{l}\text { January - } \\
\text { December } \\
1993\end{array}$} & ES & remnant forest $A$ & Shan 1 \\
\hline & & remnant forest $B$ & Shan 2 \\
\hline & & $\begin{array}{l}\text { rice-paddy } \\
\text { margin (open land }\end{array}$ & Shan E \\
\hline \multicolumn{2}{|c|}{$\begin{array}{l}\text { August } 1992 \text { - GA } \\
\text { December }\end{array}$} & $\begin{array}{l}\text { margin of } \\
\text { Pariquera- }\end{array}$ & Shan GA \\
\hline \multicolumn{2}{|l|}{1993} & Açu river & \\
\hline
\end{tabular}

As Shan 1 and Shan 2 traps operated alternatedly once a week, the total number of mosquitoes caught corresponded to the fortnightly rhythm.

Human bait (BC) collections:

$\begin{array}{lll}\text { Period } & \text { Site } & \text { Place } \\ \text { August 1992- } & \text { BC } & \text { dwelling in the ES area } \\ \text { December 1993 } & & \end{array}$

BC - "Sítio Barra do Capinzal"; ES - Experimental Station; Ga - "Galiléia Farm"

Biting activity was estimated through the Williams' mean $\left(\bar{X}_{w}\right)$, the domiciliation degree estimation was made by the synanthropic index(s) comparing it through the synanthropic ratios(sr). Besides, considering the several sites as representative of development phases, the index of change (IC) was calculated for the abundance comparison at each of these phases.
Data about the climatic conditions during the period were obtained directly from the climatology Section of the Campinas Agronomic Institute (Instituto Agronômico de Campinas) of S. Paulo State.

\section{Results}

A total of 1,880 adult mosquitoes ( 1,787 females and 93 males) belonging to the subgenus Culex were obtained. From that number 1,812 (96.4\%) were caught with the Shannon traps whereas only $68(3.6 \%)$ with human bait. The species distribution follows:

\begin{tabular}{lrr} 
Species & $\mathrm{N}$ & $\%$ \\
Cx. bidens & 7 & 0.4 \\
Cx. chidesteri & 19 & 1.0 \\
Cx. corniger & 2 & 0.1 \\
Cx. coronator & 2 & 0.1 \\
Cx. coronator + Cx. usquatus & 190 & 10.1 \\
Cx. declarator & 9 & 0.5 \\
Cx. dolosus & 3 & 0.2 \\
Cx. dolosus + Cx. eduardoi & 2 & 0.1 \\
Cx. lygrus & 11 & 0.6 \\
Cx. mollis & 14 & 0.7 \\
Cx. nigripalpus & 1,464 & 77.9 \\
Cx. (Culex) sp & 157 & 8.3 \\
& \\
\cline { 2 - 2 } & 1,880 & 100.0
\end{tabular}

The results obtained from the ES and GA sites, along with the methods employed, are presented in Table 1 . It may be seen that $C x$. nigripalpus comprised $77.9 \%$ and jointly with Coronator $\mathrm{Group}(C x$. coronator and $C x$. usquatus) reached $88.1 \%$ of the total $C x$. (Culex) specimens collected. The behaviour of $C x$. nigripalpus, compared to the Coronator Group, will be deserve special attention in this paper. As females of both represented $86.0 \%$ of the total adults caught, the following data will relate to them. Specimens determined as $C x$. (Culex) sp, could not be identified below subgenus because of damages incurred during collection.

\section{Shannon Traps}

The monthly distribution of $C x$. nigripalpus and of the Coronator Group species, are presented in Tables 2 and 3. Cx. nigripalpus incidence in the open land (Shan $E$ ) of the anthropic environment (ES), that correspond to the rice fields margin, showed a February-April peak. In that agricultural environment of the ES area, $90.5 \%$ of the $C x$. nigripalpus females was caught in the FebruaryApril period. Nevertheless, it seems that adult occurrence was explosive at that time, coinciding with higher levels of precipitation and less temperature fluctuations that occurs during that time period (Fig.). The monthly distribution of the Coronator 
Table 1- Number of adult Culex (Culex) mosquitoes collected at the anthropic (ES) and partially disturbed environment (GA). August 1992 through December 1993.

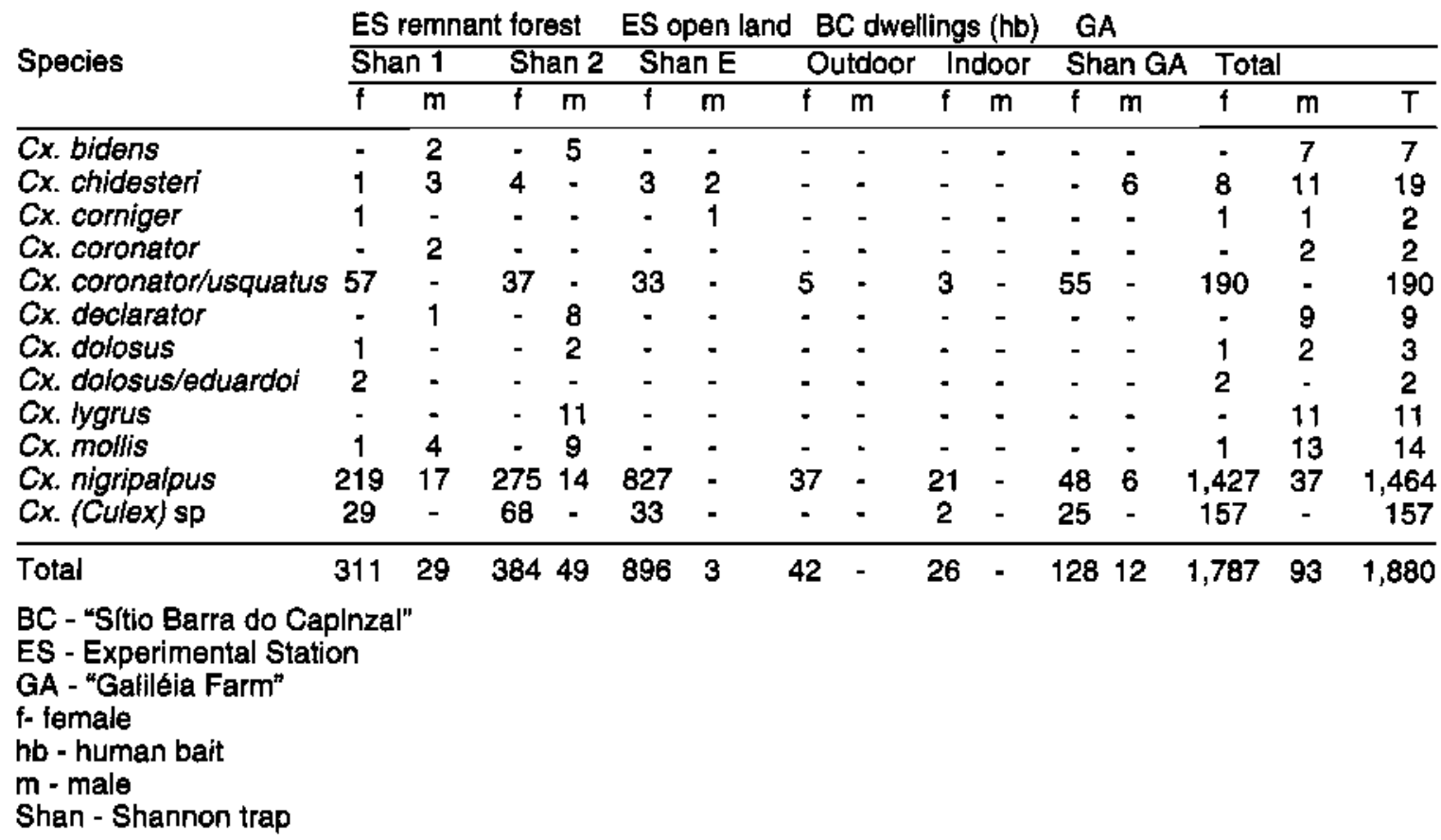

Group was more regular, apparently not influenced by environmental factors in any particular period of the year.

The data obtained in the forest patches (Shan 1 and Shan 2) were statistically compared with those from the open land (Shan E) (Table 2). Through the Mann-Whitney test the $p$ values were 0.8918 for $C x$. nigripalpus and 0.0464 for the Coronator Group, resulting in some significance for this second group of mosquitoes.

In the partially disturbed environment, represented by the GA site, irregular variations were obtained. As a general view, what may be considered a small peak occurred in March for both mosquitoes groups (Table 3 ).

\section{Domiciliary Environment}

Through the use of human bait at the BC dwelling, a total of $66 C x$. (Culex) females was caught. From that total $58(87.9 \%)$ belonged to $C x$. nigripalpus and only $8(12.1 \%)$ to the Coronator Group. According to the sampling sites, the results obtained were as follows (Table 1 and 4):

$$
\text { Indoor Outdoor Total }
$$

Cx. nigripalpus $21(87.5 \%) 37(88.1 \%) 58(87.9 \%)$

Coronator Group $3(12.5 \%) \quad 5(11.9 \%) \quad 8(12.1 \%)$

$$
\text { Total } \overline{24} \overline{42} \overline{66}
$$

Comparing the sites sampled, through the MannWhitney test, the $p$ value was 0.524 for $C x$. nigripalpus showing no significant differences between indoor and outdoor collections. Regarding the Coronator Group, the samples obtained were too small and thus insufficient for the statistical test (Table 4).

\section{Synanthropy}

Comparison of the three sampled environments was made for both mosquito groups using synanthropic indices (s). The results obtained follow:

$$
\begin{array}{lcccc} 
& \mathrm{a}(\%) & \mathrm{b}(\%) & \mathrm{c}(\%) & \mathrm{s} \\
\text { Cx. nigripalpus } & 4.2 & 60.0 & 35.8 & -1.6 \\
\text { Coronator Group } & 5.9 & 24.4 & 69.6 & -51.5
\end{array}
$$

Thus, these data suggest that $C x$. nigripalpus retained its exophilic preferences, while the Coronator Group species showed a clear sylvatic behaviour.

Considering the synanthropic ratios (sr) at the ES area, comparisons were made, between the total females caught at the open area (Shan E) jointly with that obtained in the domiciliary environment (BC), and the total caught at the remnant forests (Shan 1 and Shan 2). Doing this, the value obtained was 1.53 conjoin for both groups. The specific values were 1.75 for $C x$. nigripalpus and 0.40 for the Coronator Group. These data suggest that the residual forest patches retain greater numbers of Coronator Group mosquitoes than $C x$. nigripalpus. Besides, relating the open land (Shan E) data with those of the domiciliary environment (BC), the overall ratio was $\mathbf{1 3 . 0 3}$ for both mosquito groups considered together, showing greater occurrence 
Table 2 - Monthly dlstribution of Culex nigripalpus and Coronator Group females collected in Shannon traps at the anthropic environment area (ES), January through December 1993.

\begin{tabular}{|c|c|c|c|c|c|c|c|}
\hline \multirow[b]{2}{*}{ Months } & \multirow[b]{2}{*}{ Shan } & \multicolumn{2}{|c|}{ Cx. nigripalpus } & \multicolumn{2}{|c|}{ Coronator Group } & \multicolumn{2}{|c|}{ Total } \\
\hline & & $\mathrm{n}$ & $\%$ & $\mathbf{n}$ & $\%$ & $n$ & $\%$ \\
\hline \multirow[t]{3}{*}{ January } & 1 & - & - & - & - & - & - \\
\hline & 2 & 1 & * & 3 & 2.4 & 4 & 0.3 \\
\hline & E & : & - & - & - & - & - \\
\hline \multirow[t]{2}{*}{ February } & $\begin{array}{l}1 \\
2\end{array}$ & $\begin{array}{l}60 \\
80\end{array}$ & $\begin{array}{l}4.5 \\
6.1\end{array}$ & $\begin{array}{l}3 \\
22\end{array}$ & $\begin{array}{l}2.4 \\
17.3\end{array}$ & $\begin{array}{l}63 \\
102\end{array}$ & $\begin{array}{l}4.4 \\
7.0\end{array}$ \\
\hline & $\mathrm{E}$ & 4 & $\begin{array}{l}0.1 \\
0.3\end{array}$ & 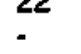 & & & 0.3 \\
\hline \multirow[t]{3}{*}{ March } & 1 & 140 & 10.6 & 2 & 1.6 & 142 & 9.8 \\
\hline & 2 & 166 & 12.6 & - & - & 166 & 11.5 \\
\hline & $\overrightarrow{\mathrm{E}}$ & 718 & 54.4 & - & - & 718 & 49.6 \\
\hline \multirow[t]{3}{*}{ April } & 1 & 12 & 0.9 & 7 & 5.5 & 19 & 1.3 \\
\hline & 2 & 5 & 0.4 & 1 & 0.8 & 6 & 0.4 \\
\hline & $\bar{E}$ & 10 & 0.8 & 6 & 4.7 & 16 & 1.1 \\
\hline \multirow[t]{3}{*}{ May } & 1 & - & - & 1 & 0.8 & 1 & $*$ \\
\hline & 2 & - & - & - & - & - & - \\
\hline & $\mathbf{E}$ & 1 & * & 7 & 5.5 & 8 & 0.6 \\
\hline \multirow[t]{3}{*}{ June } & 1 & - & - & 1 & 0.8 & 1 & $*$ \\
\hline & 2 & 2 & 0.2 & - & - & 2 & 0.1 \\
\hline & $E$ & - & - & 1 & 0.8 & 1 & $*$ \\
\hline \multirow[t]{3}{*}{ July } & 1 & 2 & 0.2 & 6 & 4.7 & 8 & 0.6 \\
\hline & 2 & - & $\cdot$ & 1 & 0.8 & 1 & $\star$ \\
\hline & $E$ & 9 & 0.7 & 1 & 0.8 & 10 & 0.7 \\
\hline \multirow[t]{3}{*}{ August } & 1 & - & - & 12 & 9.4 & 12 & 0.8 \\
\hline & 2 & $\theta$ & 0.6 & 1 & 0.8 & 9 & 0.6 \\
\hline & $\mathbf{E}$ & - & - & 5 & 3.9 & 5 & 0.3 \\
\hline \multirow[t]{3}{*}{ September } & $\overline{1}$ & 2 & 0.2 & 13 & 10.2 & 15 & 1.0 \\
\hline & 2 & 1 & $\star$ & 1 & 0.8 & 2 & 0.1 \\
\hline & E & 15 & 1.1 & 7 & 5.5 & 22 & 1.5 \\
\hline \multirow{3}{*}{ October } & 1 & 1 & * & 9 & 7.1 & 10 & 0.7 \\
\hline & 2 & 12 & 0.9 & 8 & 6.3 & 20 & 1.4 \\
\hline & $\bar{E}$ & - & - & - & - & - & $=$ \\
\hline \multirow[t]{3}{*}{ November } & $\overline{1}$ & - & - & 3 & 2.4 & 3 & 0.2 \\
\hline & 2 & - & - & - & - & - & - \\
\hline & $E$ & 44 & 3.3 & 6 & 4.7 & 50 & 3.5 \\
\hline \multirow{3}{*}{ December } & 1 & 2 & 0.2 & . & - & 2 & 0.1 \\
\hline & 2 & - & $-\cdot$ & - & - & - & - \\
\hline & $\mathbf{E}$ & 26 & 2.0 & - & $\cdot$ & 26 & 1.8 \\
\hline & 1 & 219 & 16.6 & 57 & 44.9 & 276 & 19.1 \\
\hline Total & 2 & 275 & 20.8 & 37 & 29.1 & 312 & 21.5 \\
\hline & $E$ & 827 & 62.6 & 33 & 26.0 & 860 & 59.4 \\
\hline$T$ & & 1,321 & 100.0 & 127 & 100.0 & 1,448 & 100.0 \\
\hline
\end{tabular}

ES - Experimental Station

Shan - Shannon trap

* - less than 0.1

Cx. nigripalpus:

outside than inside domiciliary environments. Nevertheless, specifically calculated for each of these mosquito groups were 15.31 for $C x$. nigripalpus and 4.1 for the Coronator Group, showing greater occurrence outside than inside the dwelling environment. However, as shown in Table 1, the results obtained with the dwelling catches of Coronator Group were quite negligible. Considering the two groups, separately, the calculated ratios were:

$$
\begin{gathered}
s r=\frac{\text { Shan } E}{\operatorname{Shan~} 1+\operatorname{Shan} 2}=1.67 \\
s r=\frac{B C}{\operatorname{Shan} E}=0.67
\end{gathered}
$$

Coronator Group:

$$
\begin{gathered}
s r=\frac{\text { Shan } E}{\operatorname{Shan~} 1+\operatorname{Shan} 2}=0.34 \\
s r=\frac{B C}{\operatorname{Shan} E}=0.24
\end{gathered}
$$


Table 3 - Monthly distribution of Culex nigripalpus and Coronator Group females collected in Shannon trap in the partially disturbed environment (GA). August 1992 through December 1993.

\begin{tabular}{|c|c|c|c|c|c|c|c|}
\hline \multirow{2}{*}{\multicolumn{2}{|c|}{ Year / Months }} & \multicolumn{2}{|c|}{ Cx. nigripalpus } & \multicolumn{2}{|c|}{ Coronator Group } & \multicolumn{2}{|c|}{ Total } \\
\hline & & n. & $\%$ & n. & $\%$ & n. & $\%$ \\
\hline \multicolumn{8}{|l|}{$\overline{1992}$} \\
\hline & August & 14 & 29.2 & 2 & 3.6 & 16 & 15.5 \\
\hline & September & 6 & 12.5 & 2 & 3.6 & 8 & 7.8 \\
\hline & October & 8 & 16.7 & - & - & 8 & 7.8 \\
\hline & November & 3 & 6.2 & 10 & 18.2 & 13 & 12.6 \\
\hline & December & - & - & - & - & - & - \\
\hline \multicolumn{8}{|l|}{1993} \\
\hline & January & - & - & 7 & 12.7 & 7 & 6.8 \\
\hline & February & - & - & - & - & - & - \\
\hline & March & 10 & 20.8 & 11 & 20.0 & 21 & 20.4 \\
\hline & April & 1 & 2.1 & 3 & 5.5 & 4 & 3.9 \\
\hline & May & 1 & 2.1 & 3 & 5.5 & 4 & 3.9 \\
\hline & June & - & - & 3 & 5.5 & 3 & 2.9 \\
\hline & July & - & - & - & - & - & - \\
\hline & August & 1 & 2.1 & 12 & 21.8 & 13 & 12.6 \\
\hline & September & - & - & 2 & 3.6 & 2 & 1.9 \\
\hline & October & 2 & 4.2 & - & - & 2 & 1.9 \\
\hline & November & 2 & 4.2 & - & $\cdot$ & 2 & 1.9 \\
\hline & December & $\cdot$ & - & $\cdot$ & $\cdot$ & $\cdot$ & $\cdot$ \\
\hline \multicolumn{2}{|l|}{ Total } & 48 & $\$ 00.1$ & 55 & 100.0 & 103 & 99.9 \\
\hline
\end{tabular}

GA - "Galiléia Farm"

Table 4 - Monthly distribution of Culex nigripalpus and Coronator Group females collected through human bait in the domiciliary environment (BC). August 1992 through December 1993.

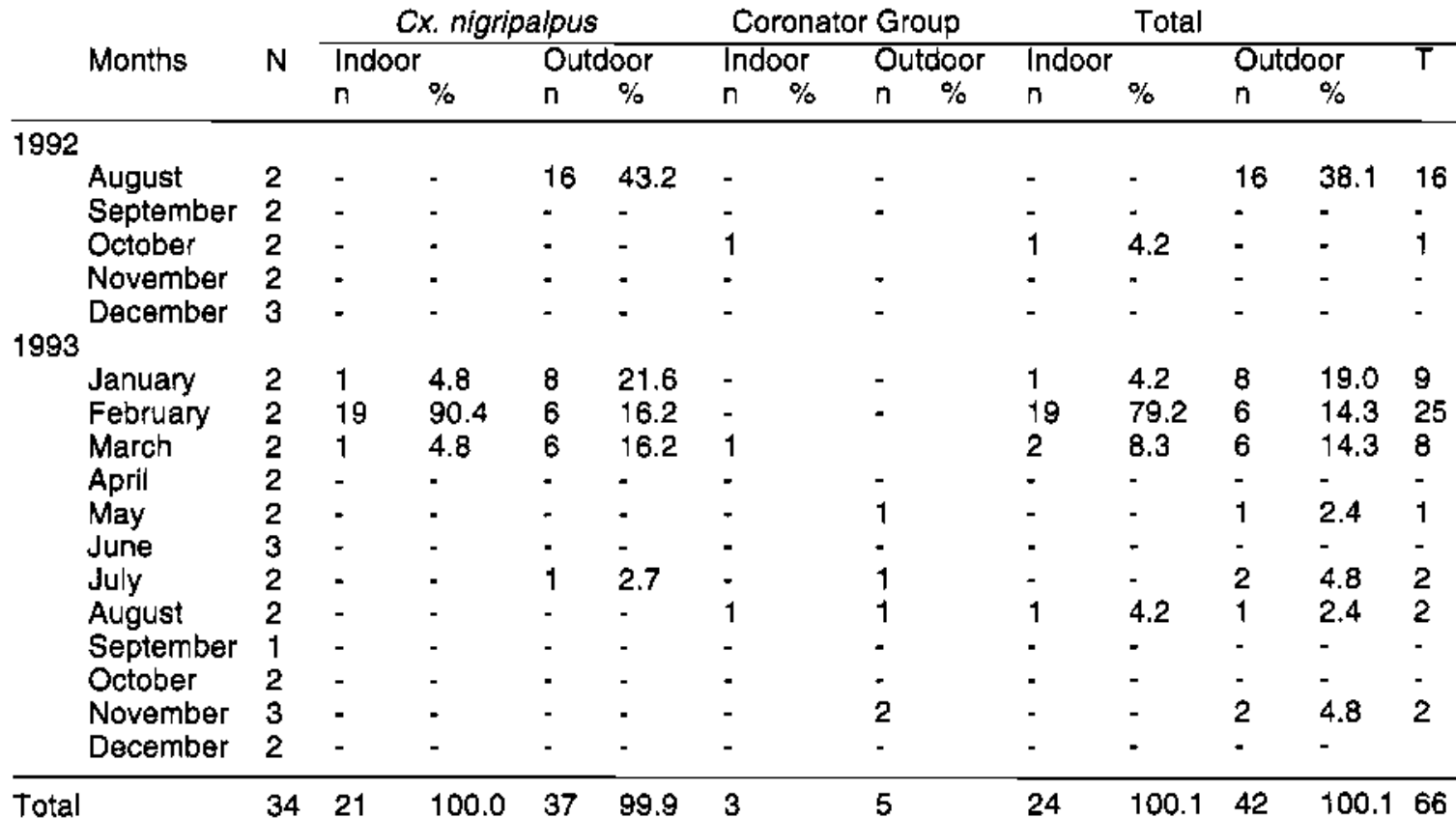

BC - "Sítio Barra do Capinzal"

$\mathrm{N}$ - number of catches 


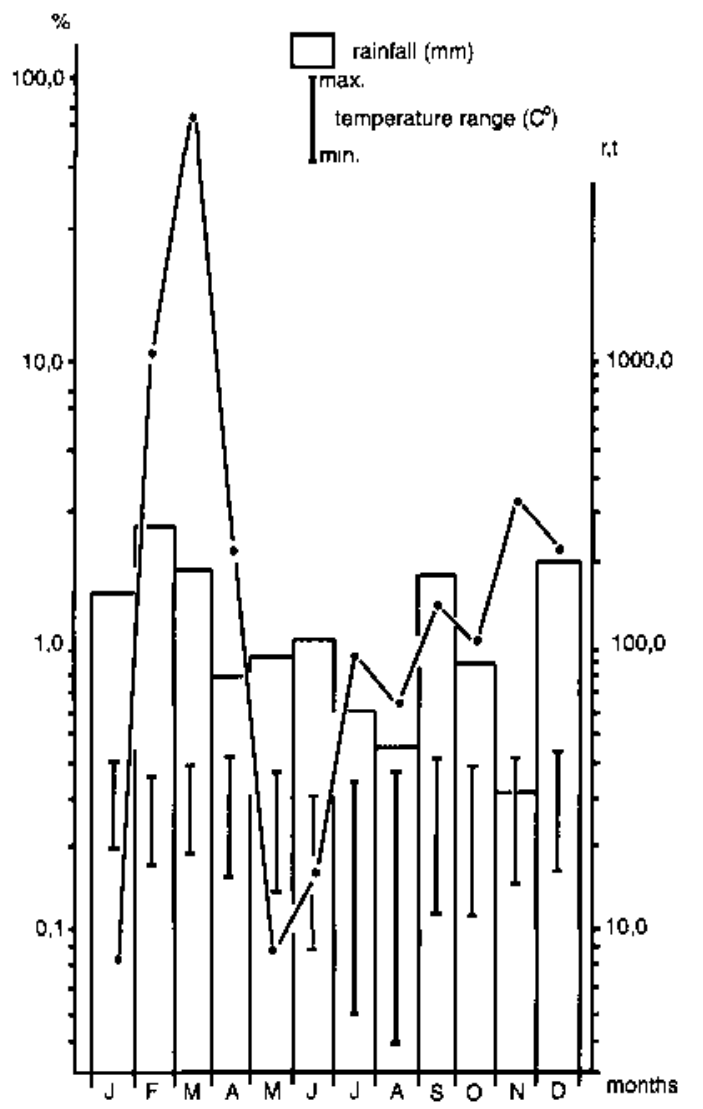

Figure- Monthly incidence of females $C_{X}$. nigripalpus in the anthropic environment of the Experimental Station (ES), caught throught Shannon traps during January-December 1993 period.

$r, t$ - total mms monthly rainfalls $(r)$ and monthly $O C$ temperature range $\langle\mathrm{t}$ ).

$\%$ - percentage from the total females caught.

In the domiciliary environment (BC) both $C x$. nigripalpus and the Coronator Group species showed a lower synanthropy level. A clear tendency to reach dwellings, in a significant manner, was not detected.

Behavioural succession, estimated through the index of change (IC), compares phase 1 (Shan $1+$
Shan 2) with the phase 2 (Shan E + BC) (Table 5). These indices were calculated as 0.9853 for $C x$. nigripalpus and 0.3433 for the Coronator Group, indicating changes for both these mosquitoes groups. Estimating the changes from phase 1 to phase 2, that mosquito increased 126.31 times while the others increased only 2.04 times.

\section{Discussion}

Among the mosquitoes sampled in the collections reported above, $C x$. nigripalpus predominated among the $C x$. (Culex) species. The Coronator Group species were second in frequency. In previous studies in the same Ribeira Valley region $C x$. nigripalpus was constantly poorly represented in collections taken inside the primitive forest environment but readily found in the modified areas represented by remnant and secondary forests (Forattini et al. ${ }^{79,13}$, $1986,1989,1993$ ). Probably this pattern may be related to sampling performed at the forest ground, as this mosquito seems to have a good degree of acrodendrophily (Guimarāes et al. ${ }^{19}, 1985$ ). Nonetheless, at least in southern Brazil, $C x$. nigripalpus may frequent anthropic modified environments, in some localities (Lourenço-de-Oliveira ${ }^{22}$, 1984). Besides, in the results reported here, no difference was observed between the remnant forest and the open cultivated land of the anthropic environment, regarding collections of that mosquito. The Coronator Group showed a slight preference for the remnant forest environment. An insufficient number of females caught limited the meaning of the statistical analysis. Regarding the data obtained at the partially disturbed environment of the GA site, no difference was found between those two mosquito groups.

The monthly distribution of $C x$. nigripalpus in the ES cultivated environment shown a major peak in February-April. This period coincided with the beginning of the fallow uncultivated phase of the rice paddies cycle. Thus, it followed the crop harvesting phase where the empty rice fields and in-

Table 5 - Index of change (IC) and abundance (a) ratios of $C X$. nigripalpus and Coronator Group females in two environment developmental phases.

\begin{tabular}{lllllllll} 
Species & \multicolumn{2}{l}{ Phase 1 (Shan 1+Shan 2) } & \multicolumn{2}{l}{ Phase 2 (Shan E+ BC) } & IC & $\mathrm{a}_{2} / \mathrm{a}_{1}$ \\
\cline { 2 - 9 } & $\mathrm{d}$ & 0 & $\mathrm{a}_{1}$ & $\mathrm{~d}$ & 0 & $\mathrm{a}_{2}$ & & \\
\hline CX. nigripalpus & 0.0012 & 0.023 & $2.85 \times 10^{-5}$ & 0.021 & 0.017 & 0.0036 & 0.9853 & 126.31 \\
Coronator Group & 0.002 & 0.0043 & $8.8 \times 10^{-6}$ & 0.023 & 0.00077 & $1.8 \times 10^{-5}$ & 0.3433 & 2.04
\end{tabular}

$a_{1}$ - overall abundance in the phase 1.

$a_{2}$ - overall abundance in the phase 2 .

d- relative density.

0 - percentage occurrence.

Shan $1+$ Shan 2 - remnant forests

Shan E + BC - open cultivated land. 
creased rainfall favoured larval breeding. However, that association seems quite variable and remains unclear (Forattini et al. $\left.{ }^{12,15}, 1993,1994\right)$. Anyway, the results seem to correlate with an increase in rainfall and higher temperature levels (Fig.), as was observed in others regions of southern Brazil (Guimaräes and Arle ${ }^{18}, 1984$; Lourenço-de-Oliveira et al. ${ }^{23}, 1985$ ).

Considering the domiciliary environment, the data obtained were insufficient to estimate the Williams'means. For $C x$, nigripalpus, no significant difference was evident between indoor and outdoor catches. About its synanthropic level, the estimation based on the $s$ indices, gave lower values, around the independence degree $(0.0)$. No clear tendency to enter dwellings was detected, even through the $s r$ ratios.

Finally, the changing pattern of the succession, estimated by the indices of change (IC), indicate that changes occurred for $C x$. nigripalpus. These results agree with what was said at the beginning of this discussion. Certainly that mosquito, at least in this southem region of Brazil, is favoured by the man-made environment, even though not reaching, in a significant manner, human habitations.

These data obtained in the Ribeira Valley region support the hypothesis that $C x$. nigripalpus may fulfill a role in the local arbovirus cycle. Its biting habits were reported elsewhere and, if not definitive, they suggested that this and other $C x$. (Culex) mosquitoes, some having even a great degree of ornithophily, may develop a suitable level of anthropophily (Lourenço-de-Oliveira and Heyden ${ }^{24}$, 1986; Guimarāes et al. ${ }^{20}, 1987$; Forattini et al. ${ }^{9}$, 1989). So, in southem Brazil, Cx. nigripalpus at least deserves attention as a possible vector of arboviruses. Among these viruses, the St. Louis encephalitis maybe transmited ouside the domiciliary environment.

\section{References}

1. BELLE, E. A.; GRANT, L. S.; PAGE, W. A. The isolation of St. Louvs encephalitis virus from Culex nigripalpus mosquitoes in Jarnaica. Am. J. Trop. Med. Hyg., 13: 4524, 1964.

2. CHAMBERLAIN, R. W.; SUDIA, W, D.; COLEMAN, P. H.; BEADLE, L. D. Vectors studies in the St. Louis encephalitis epidemic, Tampa Bay area, Florida, 1962. Am. J. Trop. Med. Hyg., 13: 456-61, 1964.

3. CUPP, E. W.; SCHERER, W. F.; LOK, J. B.; BRENNER, R. J.; DZIEM, G. M.; ORDONEZ, J. V. Entomological studies at an enzootic venezuelan equine encephalitis virus focus in Guatemala, 1977-1980. Am. J. Trop. Med. Hyg., 35: 851-9, 1986.

4. DOW, R. P.; COLEMAN, P. H.; MEADOWS, K.E.; WORK, T. H. Isolation of St. Louis encephalitis viruses from mosquitoes in the Tampa Bay area of Florida during the epidemic of 1962. Am. J. Trop. Med. Hyg., 13: 462-8, 1964.

5. DUTARY, B. E.; PERALTA, P. H.; PETERSEN, J.L. Estudios biologicos del virus de la encefalitis de San Luis en Maje,
Bayano. Rev. Med. de Panama, 9: 200-11, 1984.

6. FORATTINI, O. P.; GOMES, A. de C.; SANTOS, J. L. F.; GALATI, E. A. B.; RABELLO, E. X; NATAL, D. Observaçōes sobre atividade de mosquitos Culicidae em mata residual no Vale do Ribeira, Sāo Paulo, Brasil. Rev. Saúde Pública, 15: 557-86, 1981.

7. FORATTINI. O. P.; GOMES, A. de C.; NATAL, D.; SANTOS, J, L. F. Observaçб̌ses sobre atividade de mosquitos Culicidae em mata primitiva da encosta no Vale do Ribeira, Săo Paulo, Brasil. Rev. Saúde Pública, 20: 1-20, 1986.

8. FORATTINI, O. P.; GOMES, A. de C.; NATAL, D.; SANTOS, J. L. F. Observaçð̌es sobre atividade de mosquitos Culicidae em matas primitivas da planície e perfis epidemiológicos de vários ambientes no Vale do Ribeira, São Paulo, Brasil. Rev. Saúde Pública, 20: 178-203, 1986.

9. FORATTINI, O. P.; GOMES, A. de C.; NATAL, D.; KAKITANI, I.; MARUCCI, D. Preferências alimentares e domiciliaçăo de mosquitos Culicidae no Vale do Ribeira, São Paulo, Brasil com especial referência a Aedes scapularis a Culex (Melanoconion). Rev. Saúde Pública, 23: 9-19, 1989.

10. FORATTINI, O. P.; GOMES, A. de C.; KAKITANI, I. Observaçðes sobre mosquitos Culicidae adultos em cultivo irrigado de arroz no Vale do Ribeira, Estado de Sāo Paulo, Brasil. Rev. Saúde Pública, 23: 307-12, 1989.

11. FORATTINI, O. P.; GOMES, A. de C.; SANTOS, J. L. F.; KAKITANI, I,; MARUCCI, D. Frequência ao ambiente humano e dispersāo de mosquitos Culicidae em áreas adjacentes à mats atlântica primitiva da planície. Rev. Saude Publica, 24: 101-7, 1990.

12.FORATTINI, O. P.; KAKITANI, I.; MASSAD, E.; MARUCCI, D. Studies on mosquitoes (Diptera: Culicidae) and anthropic environment. 2 - Immature stages at a rice irrigation system location in SouthEastem Brazil. Rev. Saúde Pública, 27: 227-36, 1993.

13. FORATTINI, O. P.; KAKITANI, I.; MASSAD, E.; MARUCCI, D. Studies on mosquitoes (Diptera: Culicidae) and anthropic environment. 3 - Survey of adult stages at the rice irrigation system and the emergence of Anopheles albitarsis in South-Eastern Brazil. Rev. Salide Publica, 27; 313-25, 1993.

14, FORATTINI, O. P.; KAKITANI, I.; MASSAD, E.; MARUCCI, D. Studies on mosquitoes (Diptera: Culicidae) and anthropic environment. 4 - Survey of resting adults and synanthropic behavior in South-Eastem Brazil. Rev. Saúde Pública, 27: 398-411, 1993.

15. FORATTINI, O. P.; KAKITANI, I.; MASSAD, E.; MARUCCI, D. Studies on mosquitoes (Diptera: Culicidae) and anthropic environment. 6 - Breeding in empty conditions of rice fields, in South-Eastem Brazil. Rev. Saúde Pública, 28: 395-9, 1994.

16. FORATTINI, O. P.; SALLUM, M. A. M.; KAKITANI, I; MASSAD, E.; MARUCCI, D. Studies on mosquitoes (Diptera: Culicidae) and anthropic environment. 8 Survey of adult behaviour of Spissipes Section species of Culex (Melanoconion) in South-Eastem Brazil. Rev. Saúde Pública, 29: 100-7, 1995.

17.FORATTINI, O. P.; KAKITANI, I.; MASSAD, E.; MARUCCI, D. Studies on mosquitoes (Diptera: Culicidae) and anthropic environment. 9 - Synanthropy and epidemiological vector role of Aedes scapularis in South-Eastern Brazil. Rev. Saúde Pública, 29: 199-207, 1995.

18. GUIMARÄES, A. E. \& ARLÉ, M. Mosquitos no Parque Nacional da Serra dos Órgãos, Estado do Rio de Janeiro, Brasil. I - Distribuição estacional. Mem. Inst. Oswaldo Cruz, 79: 309-23, 1984.

19. GUIMARÂES, A. E; ARLE, M.; MACHADO, R. N. M. Mosquitos no Parque Nacional da Serra dos Órgãos, 
Estado do Rio de Janeiro, Brasil. I - Distribuição vertical. Mem. Inst. Oswaldo Cruz, 80: 171-85, 1985.

20. GUIMARÃES, A. E.; ARLE, M.; MACHADO, R. N. M. Mosquitos no Parque Nacional da Serra dos Orgãos, Estado do Rio de Janeiro, Brasil. IV - Pteferência alimentar. Mem. Inst. Oswaldo Cruz, 82: 277-85, 1987.

21. IVERSSON, L, B. Rocio encephalitis. In: Monath, T. P., ed. The arboviruses: epidemiology and ecology. Boca Raton, CRC Press Inc. 1988. v.4, p. 77-92.

22. LOURENÇO-DE-OLIVEIRA, R. Alguns aspectos da ecologia de mosquitos (Diptera: Culicidae) de uma área de planície (Granjas Calábria), em Jacarepaguá, Rio de Janeiro. I. Frequêtncia comparativa das espécies em diferentes ambiente e métodos de coleta. Mem. Inst. Oswaldo Cruz, 79: 479-90, 1984.

23. LOURENÇO-DE-OLIVEIRA, R.; SILVA, T. F.; HEYDEN, R. Alguns aspectos da ecologia de mosquitos (Diptera: Culicidae) de uma área de planf́cie (Granjas Calábria), em Jacarepaguá, Rio de Janeiro. II. Frequência mensal e no ciclo lunar. Mem. Inst. Oswaldo Cruz, 80: 123-33, 1985.

24. LOURENÇO-DE-OLIVEIRA, R. \& HEYDEN, R. Alguns aspectos da ecologia de mosquitos (Diptera: Culicidae) de uma área de planície (Granjas Calábria), em
Jacarepaguâ, Rjo de Janeiro. IV. Preferências alimentares quanto ao hospedeiro e freqüência domiciliar. Mem. Inst. Oswaldo Cruz, 81: 15-27, 1986.

25. MITCHELL, C. J.; CABRERA, F. A.; DAGGERS, S. A.; JAKOB, W. L. Arthropod collected in the Dominican Republic during an outbreak of Eastem Equine Encephalitis. Mosquito News, 39: 263-7, 1979.

26. MTCHELL, C. J.; MONATH, T. P.; SABATTINI, M. S.; CROPP, C. B.; DAFFNER, J. F.; CALISHER, C. H.; JAKOB, W. L.; CHRISTENSEN, H. A. Arbovirus investigations in Argentina, 1977-1980. If. Arthropod collections and virus isolations from argentine mosquitoes. Am. J. Trop. Med. Hys., 34: 945-55, 1985.

27. MORRIS, C. D. Eastern equine encephalitis. J. Florida Mosq. Control Ass., 63: 23-34, 1992.

28. VASCONCELOS, P.F. da C; TRAVASSOS DA ROSA, J.F, S; TRAVASSOS DA ROSA, A. P. de A.; DEGALLIER, N.; PINHEIRO, F. de P.; SA FLLHO, G. C. Epidemiologia das encefalites por arbavírus na Amazónia brasileira. Rev. Inst. Med. Trop. S. Paulo, 33: 465-76, 1991.

29. WEBB, P. A. \& HOLBROOK, F. R. Vesicular stomatitis. In: Monatth, T. P. ed. The arboviruses: epidemiology and ecology. Boca Raton, CRC Press Inc, 1988. v.5, p. 1-29.

\section{Resumo}

Săo relatados os resultados obtidos mediante coletas regulares de adultos de Culex (Culex) em ambientes antrópico do Vale do Ribeira, SP, Brasil, no periodo de agosto de 1992 a dezembro de 1993. Pode-se evidenciar a dominancia de Culex nigripalpus nas várias coletas efetuadas. Revelou-se claramente a preferéncla por parte desse mosquito em aumentar sua densidade no ambiente antrópico. Todavia, sua freqüencia ao domiclio mostrou-se baixa, revelando traco grau de sinantropia. Assim sendo, seu papel vetor de arbovirus parece restringir-se à participacāo no ciclo natural desses agentes infecciosos. Contudo, pode-se considerá-lo como vetor potencial no meio extradomiciliar. Nesse particular, seu papel pode nāo ser negligenciável, especialmente no que tange a possibilidade de transmissáo de encefalite de S. Luís, cujo agente já foi assinalado na regiäo.

Culex. Ecologia de vetores. Encefalite de St. Louis, transmission. 